Influence of mulching on virus disease incidence, growth and yield of sweet pepper (Capsicum annuum)

Utjecaj malčiranja na učestalost virusnih bolesti, rast i prinos slatke paprike (Capsicum annuum)

Arogundade O., Salawu, A., Osijo, A., Kareem, K.T.

Poljoprivreda/Agriculture

ISSN: 1848-8080 (Online)

ISSN: 1330-7142 (Print)

http://dx.doi.org/10.18047/poljo.25.2.6

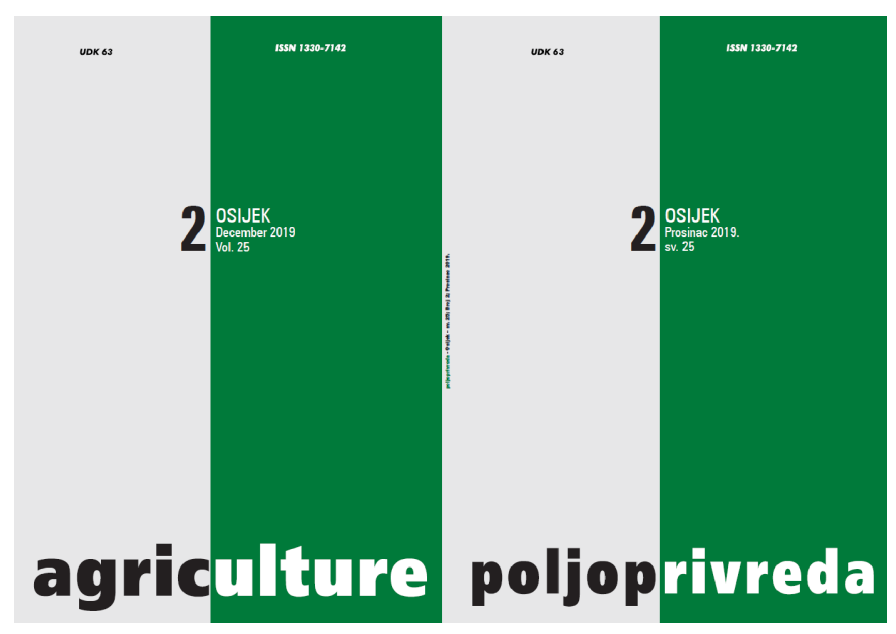

Fakultet agrobiotehničkih znanosti Osijek, Poljoprivredni institut Osijek

Faculty of Agrobiotechnical Sciences Osijek, Agricultural Institute Osijek 
ISSN $1330-7142$

$U D K=635.649: 632.38$

DOI: $10.18047 /$ poljo.25.2.6

\title{
INFLUENCE OF MULCHING ON VIRUS DISEASE INCIDENCE, GROWTH AND YIELD OF SWEET PEPPER (Capsicum annuum)
}

Arogundade 0.(1), Salawu, A. ${ }^{(2)}$, Osijo, A. ${ }^{(1)}$, Kareem, K.T. ${ }^{(2)}$

\begin{abstract}
SUMMARY
Sweet pepper is attacked by a number of viruses which cause serious yield losses for many growers. The influence of mulching on virus disease incidence in sweet pepper was studied under irrigation in NIHORT. Healthy seedlings were transplanted to the field and arranged in a randomized complete block design (RCBD). Different mulch used included air-dried leaves of Azadirachta indica (Neem), Tithonia diversifolia (Tithonia), Neem + Tithonia (w/w) and plastic mulch (white, black and yellow) while the control had no mulch. Incidence and severity of virus-like diseases on growth and yield were evaluated. Result indicated that plants grown using white plastic mulch had the lowest disease incidence of $34.43 \%$. Plants grown with Tithonia, Neem, and Neem + Tithonia mulch had high disease incidence of $100 \%, 88 \%$, and $90.60 \%$ respectively. Average virus disease severity ranged from 2.30 and 3.33 on a scale of 1-5 scoring system. Symptoms observed on symptomatic plants include mosaic, mottle, wrinkle and leaf reduction. Plots treated with black plastic mulch produced the lowest fruit weight, while the white and yellow plastic mulch induced highest fruit weight found. The results obtained showed that white and yellow plastic mulches are effective management options for viruses of sweet pepper.
\end{abstract}

Original scientific paper

Izvorni znanstveni članak

Keywords: sweet pepper, virus incidence, mulch, disease severity, symptom, control

\section{INTRODUCTION}

Sweet pepper (Capsicum annuum) is one of the most common and extensively cultivated crop species in the tropics and subtropics (Ekue et al., 2010). They produce a wide variety of fruit shapes and sizes. While some are mild and green, others are hot and red. The plant, although named annuum, is not an annual crop but can survive and grow into a large perennial shrub (Kouassi et al., 2012). Domesticated varieties within the genus Capsicum contain diverse edible fruits with pungent taste (Tewksbury et al., 2006). The seeds are high in capsaicin which also is present in the fleshy membrane of both sweet and hot peppers (Nwokem et al., 2010). Capsicum sp. is attacked by a large number of pathogens and many yield losses are caused by viruses most of which are vectored by whitefly and aphids (Arogundade et al., 2014). Whitefly vectors are highly polyphagous (Kucharek, 2004). However, magnitude of their infestation and nature or injury extent vary with plant species, seasons and localities (Greathead, 1986).
Aphid vectors transmit about 39 percent of all known plant virus (Nault, 2000). Aphids and whiteflies are by far the most important insects transmitting nearly two-third of insect-transmitted plant viruses. Some viruses are only associated with the insect mouthparts (non-circulative), while others are retained in the salivary glands after moving through the insect body (circulative) (Kucharek, 2004). Generally, various insect species may serve as volunteer vectors of plant viruses, but whitefly and aphids remain most economically important (Greathead, 1986).

Surface mulching with synthetic plastic sheets or natural organic wastes are used to protect crops against many soil pathogens and insects ensuring good growth and yield (Ahmad, 2009). Neem and Tithonia leaves are used as insect repellant. These organic mulches also

(1) Assist. Prof. Olawale Arogundade larogundade olawale@yahooo. co.uk), MSc. Adeyemi Osijo - National Horticultural Research Institute, Jericho Reservation Area, Idi-Ishin, PMB 5432, Ibadan, Oyo State, Nigeria, (2) Abiodun Salawu, OND, Assist. Prof. Kehinde T. Kareem - Institute of Agricultural Research and Training (IAR\&T), P.M.B 5029, Moor Plantation, Ibadan, Oyo State, Nigeria 
aid moisture conservation, temperature amelioration and weed control (Awodoyin and Ogunyemi, 2005). Synthetic mulches are reported to have been very effective for vegetable growth and yield by improving microclimate around the plant (Bosland and Votava, 2012). Most clear, black or colored plastic mulch influence the soil microclimate differently based on their reflective properties. They are used to preserve plant moisture content, soil temperature and minerals needed by plants (Saeed and Ahmad, 2009). These have also been used to obtain good yield in solanaceous crops like Irish potato (Solanum tuberosum), tomato (Lycopersicum esculentum), sweet potato (Ipomoea batatas) and pepper (Capsicum spp.), Rahman et al. (2006). However, cost implication and difficulty of disposing used colored plastic mulch materials have sometimes inhibited adoption of these methods (Mahmoudpour and Stapleton, 1997). This study is aimed at evaluating the influence of different mulch materials on the incidence and severity of viral diseases, and its effect on growth and yield attributes of sweet pepper.

\section{MATERIAL AND METHODS}

\section{Experimental location}

The field experiment was carried out at National Horticultural Research Institute (NIHORT), Idi-Ishin, Ibadan, Nigeria (latitude $7^{`} 54^{\circ} \mathrm{N}$, and longitude $3^{`} 54^{\circ}$ $\mathrm{E}, 213 \mathrm{~m}$ a.s.l) located in a rainforest-savanna transition ecosystem. Sweet pepper seeds were obtained from certified disease-free stock at the seed unit of NIHORT.

\section{Land preparation and seeding}

Land was prepared by mechanized ploughing and harrowing, then manually partitioned into 21 plots (beds) using a hoe. Each bed measured $1.5 \mathrm{~m} \times 1.5 \mathrm{~m}$ with $1 \mathrm{~m}$ furrow between and within rows. Pepper seedlings were raised in nursery trays for 5 weeks in a screen house to carefully control the conditions for growth and development. The nursery trays were watered thrice a week for adequate irrigation necessary for proper development before transplanting.

Treatments used included white plastic mulch (treatment 1), black plastic mulch (treatment 2), yellow plastic mulch (treatment 3), Neem-leaf organic mulch (treatment 4), Tithonia-leaf organic mulch (treatments 5), Neem-leaf + Tithonia-leaf organic mulch (treatment 6), and a control (treatment 7) where no mulch was applied. The organic mulch materials were obtained and air-dried at the College of Agriculture-IAR\&T, Ibadan-Nigeria, while plastic mulches (yellow, black and white) were purchased from Ibadan central market. Each organic mulch material was applied at the rate of $10 \mathrm{t} / \mathrm{ha}$ corresponding to $3 \mathrm{~kg}$ of mulch material per plot while plastic mulch dimension of $1.5 \mathrm{~m} \times 1.5 \mathrm{~m}$ was used on each bed.

\section{Disease incidence and severity}

All the plots were observed in each treatment for distinct virus symptoms such as leaf mosaic, leaf mottles, leaf curling, leaf malformation, plant stunting and fruits abnormalities. Disease incidence and average severity were recorded fortnightly. Disease incidence was estimated using the formula;

$$
\text { Virus incidence }(\%)=\frac{T \times 100}{D}
$$

Where, $T=$ Total number of diseased plants in a plot, $D=$ Total number of plants in a plot.

The disease severity was assessed using a 1-5 scoring system according to Arogundade et al. (2014). The rating of disease intensity was done as follows; score $1=$ Symptomless plants (no visible symptom observed), score 2 = Mild symptoms (mosaic, mottle, leaf curl, leaf reduction, puckering on at least $25 \%$ of the total plant leaves), score $3=$ Moderate symptoms (mosaic, mottle, leaf curl, leaf reduction, puckering on at least $50 \%$ of the total plant leaves), score $4=$ Severe symptoms (mosaic, mottle, leaf curl, leaf reduction, puckering on the entire plant leaves), score $5=$ Severe symptoms (mosaic, mottle, leaf curl, leaf reduction, puckering on the entire plant leaves) plus stunting of the plant. The average severity which is a reflection of the damage caused by the virus infection was calculated using the formula;

Average severity $=\frac{d s 1+d s 2+d s 3+\ldots . .+d s n}{N d n}$

Where $d s n$ is severity score of individual diseased plant and Ndn is total number of diseased plants.

\section{Growth and yield parameters}

Data was taken for numbers of leaves and number of branches by direct count. Plants height $(\mathrm{cm})$ and stem girth $(\mathrm{mm})$ was measured and recorded at two-week interval until harvest. Number of days to $50 \%$ flowering was recorded, while number of fruit and weight of fruit (g) were recorded as at when due. All data collected were subjected to analysis of variance (ANOVA) and significant means were separated using Duncan multiple range test (DMRT).

\section{RESULTS}

\section{Effect of different mulch materials on disease inci- dence}

Table 1 shows the effect of different mulch materials on disease incidence at different weeks after transplanting (WAT). The mean virus incidence values increased overtime with significant differences across the treatments at 3 WAT, 5 WAT, 7 WAT and 9 WAT. Tithonia leaves used for mulching at 5 WAT had the highest virus disease incidence $(14.13 \%)$ while no incidence of virus was observed on plots with black plastic mulch. At 7 WAT, white plastic mulch plot had the lowest disease incidence of $8.57 \%$. However, mulching with either Neem or Tithonia produced plants with high significant virus incidence. At 9 WAT, virus incidence in plots with plastic mulch was significantly lower than high virus incidence observed in plots with organic mulch. 
Table 1. Effect of different mulch materials on disease incidence.

Tablica 1. Učinak različitih materijala za malč na učestalost bolesti.

\begin{tabular}{|l|c|c|c|c|}
\hline $\begin{array}{l}\text { Mulch treatment } \\
\text { Tretman malčem }\end{array}$ & 3WAT & SWAT & 7WAT & 9WAT \\
\hline White & $0^{\mathrm{b}}$ & $3.03^{\mathrm{ab}}$ & $8.57^{\mathrm{b}}$ & $34.43^{\mathrm{c}}$ \\
\hline Black & $0^{\mathrm{b}}$ & $0^{\mathrm{b}}$ & $10.07^{\mathrm{b}}$ & $63.63^{\mathrm{b}}$ \\
\hline Yellow & $5.53^{\mathrm{a}}$ & $8.33^{\mathrm{ab}}$ & $19.43^{\mathrm{b}}$ & $50.00^{\mathrm{c}}$ \\
\hline Neem & $0^{\mathrm{b}}$ & $8.33^{\mathrm{ab}}$ & $62.37^{\mathrm{a}}$ & $88.13^{\mathrm{ab}}$ \\
\hline Tithonia & $2.77^{\mathrm{ab}}$ & $14.13^{\mathrm{a}}$ & $62.13^{\mathrm{a}}$ & $100.00^{\mathrm{a}}$ \\
\hline Neem+Tithonia & $2.77^{\mathrm{ab}}$ & $8.57^{\mathrm{ab}}$ & $30.00^{\mathrm{b}}$ & $90.60^{\mathrm{ab}}$ \\
\hline No mulch & $0^{\mathrm{b}}$ & $7.23^{\mathrm{ab}}$ & $21.10^{\mathrm{b}}$ & $61.67^{\mathrm{bc}}$ \\
\hline
\end{tabular}

Means followed by the same letters in a column are not significantly different at $\mathrm{P}<0.05$ using the New Duncan Multiple Range Test

\section{Effect of different mulch materials on virus disease severity}

The results showed that there was no significant difference among the treatments at 7 WAT, while significant differences occurred among the treatments at 3 WAT, 5 WAT and 9 WAT (Table 2). At 3 WAT, white plastic mulch, black plastic mulch, neem leaf mulch, and control treatments had average severity of 1 while yellow plastic mulch treatment had the highest average severity of 1.67 . At 5 WAT, Tithonia leaf and control (no mulch) treatment had the highest average severity of 2.0 , while neem leaf mulch had the highest average severity (2.73) at 7 WAT. At 9 WAT, highest virus severity (3.33) was observed with neem leaf mulched plot followed by Tithonia leaf mulched plot (3.30) while white plastic mulched plot had the least average severity of 2.30 .

Table 2. Effect of different mulch materials on average virus severity

Tablica 2. Utjecaj različitih materijala za malč na prosječnu težinu virusa

\begin{tabular}{|l|c|c|c|c|}
\hline $\begin{array}{l}\text { Mulch treatment } \\
\text { Tretman malčem }\end{array}$ & 3WAT & 5WAT & 7WAT & 9WAT \\
\hline White & $1.0^{\mathrm{b}}$ & $1.3^{\mathrm{ab}}$ & 2.00 & $2.30^{\mathrm{c}}$ \\
\hline Black & $1.0^{\mathrm{b}}$ & $1.0^{\mathrm{b}}$ & 2.00 & $2.90^{\mathrm{abc}}$ \\
\hline Yellow & $1.67^{\mathrm{a}}$ & $1.50^{\mathrm{ab}}$ & 2.23 & $2.73^{\mathrm{abc}}$ \\
\hline Neem & $1.0^{\mathrm{b}}$ & $1.67^{\mathrm{ab}}$ & 2.73 & $3.33^{\mathrm{a}}$ \\
\hline Tithonia & $1.33^{\mathrm{ab}}$ & $2.0^{\mathrm{a}}$ & 2.63 & $3.30^{\mathrm{a}}$ \\
\hline Neem+Tithonia & $1.33^{\mathrm{ab}}$ & $2.10^{\mathrm{a}}$ & 2.57 & $2.97^{\mathrm{ab}}$ \\
\hline No mulch & $1.0^{\mathrm{b}}$ & $2.0^{\mathrm{a}}$ & 2.10 & $2.60^{\mathrm{bc}}$ \\
\hline DMRT & & & NS & \\
\hline
\end{tabular}

Means followed by the same letters in a column are not significantly different at $\mathrm{P}<0.05$ using the New Duncan Multiple Range Test, NS $=$ not significant

\section{Effect of different mulch materials on plant height}

Results revealed that the treatments did not have significant effect on plant heights at 3 WAT and 5 WAT. Mean plant height values ranged from $10.03 \mathrm{~cm}$ to $11.83 \mathrm{~cm}$ in 3 WAT, and $10.8 \mathrm{~cm}$ to $14.37 \mathrm{~cm}$ in 5 WAT (Table 3). At 7 WAT, plots mulched with Tithonia leaves produced the shortest plants $(11.63 \mathrm{~cm})$ while Neem + Tithonia mulch plot had the tallest plants $(16.1 \mathrm{~cm})$. Neem leaf mulch treatment had the highest plant height $(16.7 \mathrm{~cm})$ at 9 WAT, while Tithonia leaf had the least plant height $(12.47 \mathrm{~cm})$.

Effect of different mulch materials on numbers of leaves

The effect of mulch materials on number of leaves showed that the treatments did not have significant effect through the weeks of observation. However, the number of leaves increased overtime. At 3 WAT, the mean value of White plastic mulched plot was 7.33 number of leaves while Yellow plastic had the mean value of 14.33 number of leaves (Figure 1). The mean values of leaf number at 7 WAT ranged between 26.67 and 38.17 while those of 9 WAT ranged from 32 to 47.33 .

\section{Effect of different mulch materials on stem girth}

Results obtained from the stem girths follow a similar trend as the number of leaves. All the treatments did not have significant effect on the stem girths and mean values increased overtime (Figure 2). At 3 WAT, plants from Neem mulched plots had the highest mean stem girth $(3.33 \mathrm{~mm})$ followed by the yellow mulched plots $(2.5 \mathrm{~mm})$, white plastic mulched plants had the smallest stem girth $(2.03 \mathrm{~mm})$. 
Table 3. Effects of different mulch materials on plant heights (cm)

Table 3. Utjecaji različitih materijala za malč na visinu biljaka (cm)

\begin{tabular}{|l|c|c|c|c|}
\hline $\begin{array}{l}\text { Mulch treatment } \\
\text { Tretman malčem }\end{array}$ & 3WAT & 5WAT & 7WAT & 9WAT \\
\hline White & 10.27 & 11.23 & $12.20^{\mathrm{bc}}$ & $16.47^{\mathrm{a}}$ \\
\hline Black & 10.97 & 11.73 & $12.60^{\mathrm{abc}}$ & $13.90^{\mathrm{ab}}$ \\
\hline Yellow & 10.80 & 11.37 & $12.80^{\mathrm{abc}}$ & $14.40^{\mathrm{ab}}$ \\
\hline Neem & 11.70 & 13.50 & $15.37^{\mathrm{ab}}$ & $16.70^{\mathrm{a}}$ \\
\hline Tithonia & 10.03 & 10.80 & $11.63^{\mathrm{c}}$ & $12.47^{\mathrm{b}}$ \\
\hline Neem+Tithonia & 10.60 & 12.93 & $16.10^{\mathrm{a}}$ & $16.57^{\mathrm{a}}$ \\
\hline No mulch & 11.83 & 14.37 & $14.30^{\mathrm{abc}}$ & $16.60^{\mathrm{a}}$ \\
\hline DMRT & NS & NS & & \\
\hline
\end{tabular}

Means followed by the same letters in a column are not significantly different at $\mathrm{P}>0.05$ using the New Duncan Multiple Range Test, NS $=$ Not significant

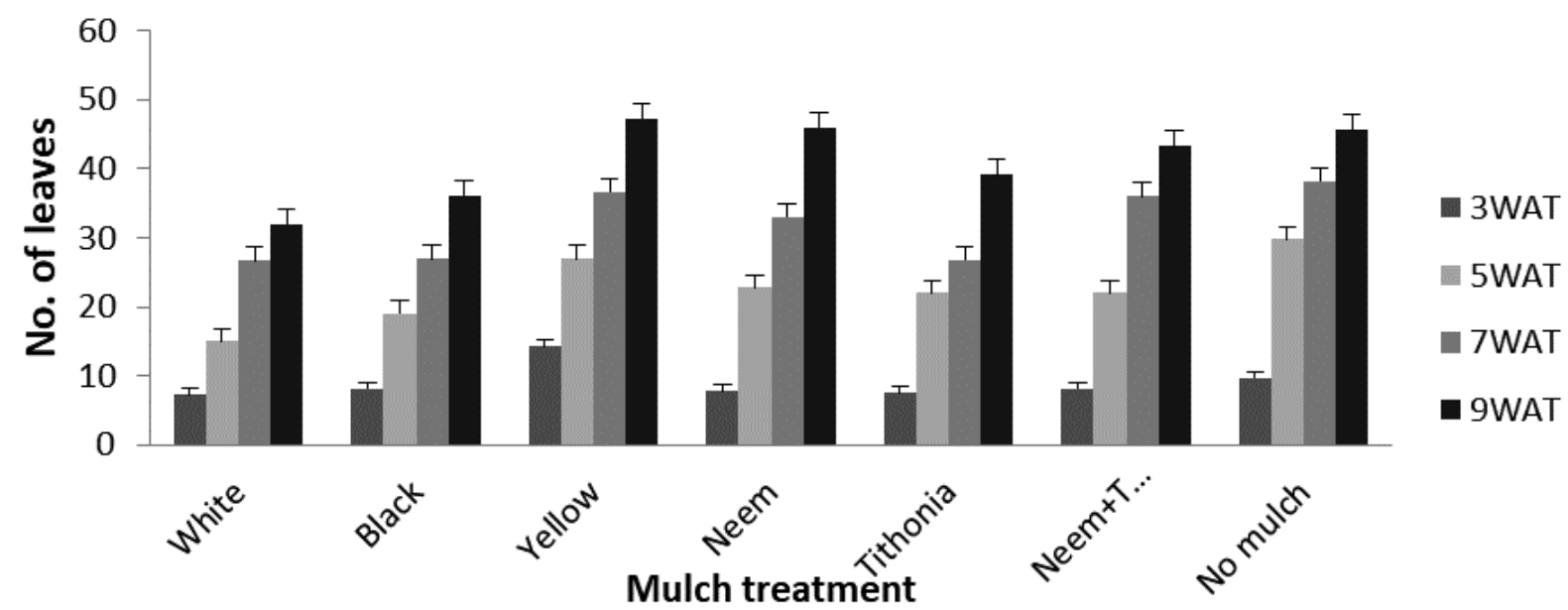

Figure 1. Effects of different mulch materials on number of leaves

Slika 1. Utjecaji različitih materijala za malč na broj listova

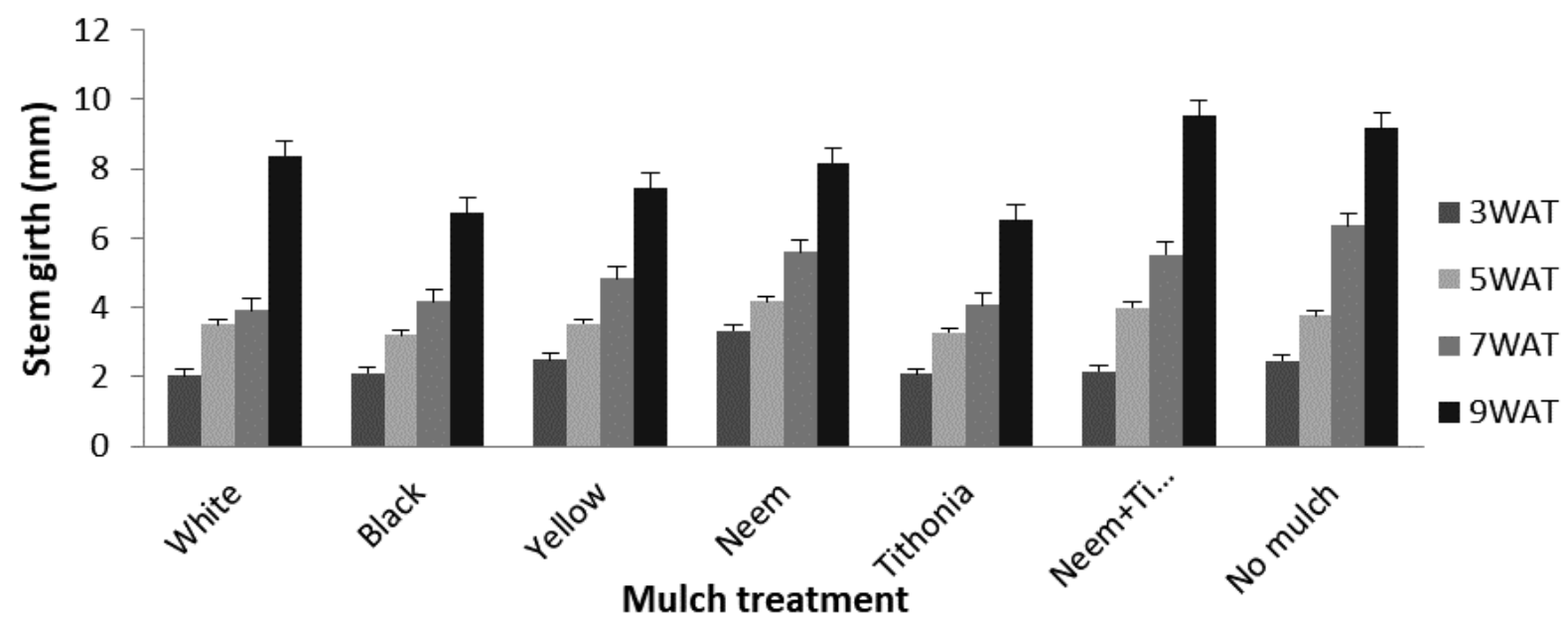

Figure 2. Effect of different mulch materials on stem girth

Slika 2. Utjecaj različitih materijala za malč na obujam stabljike 
At 5 WAT, neem leaf mulch produced plants with the highest stem girth $(4.17 \mathrm{~mm})$ followed by its combination with Tithonia. The least stem girth of $6.53 \mathrm{~mm}$ occurred with Tithonia mulch while treatment with Neem + Tithonia leaf had the highest stem girth of 9.53 $\mathrm{mm}$.

\section{Effect of different mulch materials on yield param- eters}

Yield results indicated that no significant differences occurred across the treatments (Table 4). However, data plants mulched with white and yellow plastic reached $50 \%$ flowering at 46 days after transplant (DAT) while plants in the black plastic mulch reached $50 \%$ flowering at an average of 51.33 DAT (Table 4). Organic mulched treatments induced late fruiting in plants. Tithonia leaf treatment had lowest number of fruits per plant (5.0) while yellow plastic plot had highest number of fruits per plant (10.0). Yellow plastic mulched plants had the highest fruit weight per plant $(188.17 \mathrm{~g})$ followed by Neem mulched plot (185.43 g). However, black mulched plot had the least fruit weight.

Table 4. Effects of different mulch materials on pepper yield

Table 4. Učinci različitih materijala za malč na prinos paprike

\begin{tabular}{|l|c|c|c|c|}
\hline $\begin{array}{l}\text { Mulch treatment } \\
\text { Tretman malčem }\end{array}$ & $\begin{array}{c}\text { Days to 50\% flowering } \\
\text { Dani do 50-postotne cvatnje }\end{array}$ & $\begin{array}{l}\text { Days to fruiting } \\
\text { Dani do zoridbe }\end{array}$ & $\begin{array}{c}\text { Number of fruits } \\
\text { Broj plodova }\end{array}$ & $\begin{array}{c}\text { Weight of fruits (g) } \\
\text { Težina plodova (g) }\end{array}$ \\
\hline White & 46.0 & 53.33 & 6.17 & 122.87 \\
\hline Black & 51.33 & 56.0 & 6.17 & 103.87 \\
\hline Yellow & 46.0 & 51.33 & 10.0 & 188.17 \\
\hline Neem & 50.0 & 60.0 & 9.50 & 185.43 \\
\hline Tithonia & 49.33 & 60.0 & 5.0 & 137.10 \\
\hline Neem+ Tithonia & 49.33 & 57.50 & 6.67 & 129.30 \\
\hline No Mulch & 50.0 & 50.33 & 7.67 & 150.23 \\
\hline DMRT & NS & NS & NS & NS \\
\hline
\end{tabular}

NS $=$ Not significant at $\mathrm{P}>0.05$ using the New Duncan Multiple Range Test

\section{DISCUSSION}

Viral disease incidence was significantly lower in the white and yellow plastic mulch plots than in plots with organic mulch at 9WAT. These reflective plastic mulches have been reported to reduce incidence of virus disease in bell pepper and many vegetables (Awodoyin et al., 2007; Kapoor, 2012). Vani et al. (1989) reported in their work that yellow polythene mulch reduced the incidence of mosaic disease on musk-melons. Lutzinsky et al. (1996) also reported that yellow and brown plastic mulches reduced the incidence of leaf curl in tomato rows. The high virus disease incidence and severity in the organic mulched plots could be explained by the fact that the leaves did not have such a strong insect repellant effect. Therefore, adjoining weeds could serve as alternate hosts and reservoirs of viruses and vectors. Kareem et al. (2012) have demonstrated high virus incidence and severity in okra mulched with organic materials presumably because of rapid decomposition of materials. Insect vectors can transmit the viruses to pepper plants during non-persistent feeding transmission thus bringing about the increased incidence and severity found. In addition, Awodoyin et al. (2007) reported that grasses and leafy mulch materials do not provide long cover over the soil because of rapid decomposition. Therefore, the rapid decomposition might have enhanced increase in the population of virus vectors and encouraged rapid weed re-infestation and this may increase transmission of virus diseases.

Plastic mulches have been shown to reduce insect infestation and the concurrent damage associated with the insect transmission of viruses (Bosland and Votata, 2012). Current result indicates that white and yellow plastic mulch induced lower virus incidence of pepper than black plastic mulch, and this has also been reported in previous studies (Lutzinsky et al., 1996). Plants grown over yellow plastic mulch had the highest number of fruits and highest fruit weight presumably due to its ability to withstand radiation and regulate soil microclimate (Awodoyin and Ogunyemi, 2005). Similar results were reported by Sonkar et al. (2012) where yellow polyethylene mulch significantly increased the growth, size and weight of pepper fruits. The yield attribute of pepper was low on white and black plastic mulch because of their different effect on soil microenvironment and physiological attributes. Diaz-Perez (2010) reported that both marketable and total yields were lowest on black and white mulches in the fall and spring, respectively because of their different soil warming ability. Neem mulch plot induced high number and weight of pepper fruits presumably because the neem leaves could have provided sufficient organic matter to the soil that favors development of more root hairs and nutrient absorption which were translocated to the leaves for fruit production. 


\section{CONCLUSION}

In conclusion, the use of reflective plastic mulch should be considered as means of managing virus diseases in pepper plants on the field because they are found to reduce the incidence. Yellow plastic mulch reduced virus incidence in pepper by $18.9 \%$ when compared to no mulch. Although the initial cost of using yellow plastic mulch is high, these plastic mulches ultimately reduce virus incidence, prevent weed growth and increase yield of sweet pepper.

\section{REFERENCES}

1. Ahmad, R. 2009. Vegetative growth and yield of tomatoes as affected by application of organic mulch and gypsum under saline rhizoshpere. Pakistan Journal of Botany, 41(6), 3093-3105.

2. Arogundade, O., Kareem, K. T., Lava, K. P. \& Omodele, T. 2014. Prevalence of viruses in field grown pepper in Oyo and Osun states of Nigeria. Nigerian Journal of Plant Protection, 28, 117-125. http://dx.doi.org/10.5897/AJB2015.14803

3. Awodoyin, R. 0., Ogbeide, F. I. \& Oluwole, 0. 2007. Effect of three mulch types on the growth and yield of Tomato (Lycopersicon esculentum Mill.) and weed suppression in Ibadan, Rainforests savanna transition zone of Nigeria. Tropical Agricultural Resource and Extension, 10, 53-60.

4. Awodoyin, R. 0. \& Ogunyemi, S. 2005. Use of sickle pod, Senna obtusifolia (L.) Irwin and Barneby as much interplant in cayenne pepper, Capsicum frutescens $\mathrm{L}$. production. Emirate Journal of Agricultural Science, 17(1), 10-22

https://doi.org/10.9755/ejfa.v12i1.5044

5. Bosland, P. W. \& Votata, E. J. 2012. Peppers: Vegetables and spice capsicums. 219 pp. CAB international institute. ISBN: 9781845938253.

6. Diaz-Perez, J. C. 2010. Bell pepper (Capsicum annum L.) grown on plastic film mulckes: effects on crop microenvironment, physiological attributes and fruit yield. Horticultural Science 45(8), 1196-1204. https://doi.org/10.21273/HORTSCI.45.8.1196

7. Ekue, M., Sinsin, B., Eyog-Matig, 0. \& Finkeldey, R. 2010. Uses traditional management, perception of variation and preferences in ackee (Blighiasapida K. D. Koenig) fruit traits in Benin: implication for domestication and cultivation. Journal of Ethnobiology and Ethnomedicine, 6, 12

8. Greathead, A. H. 1986. Host plants. In: M. J. W. Cock (Ed.), Bemisia tabaci - A literature survey on the cotton whitefly with an annotated bibliography (pp. 17-25). $\mathrm{CAB}$ international institute.

9. Kapoor, P. 2012. Effect of polythene mulches and barrier crops on virus disease incidence and yield of bell pepper. Indian Phytopathology, 65(4), 391-394.
10. Kareem, K. T., Alamu, 0. 0., Egberongbe, R. K. \& Arogundade, 0. 2012. Effect of different mulch materials on the incidence and severity of Okra mosaic virus (OMV) in okra plants. Journal of Applied Horticulture, 14(1), 42-46.

11. Kouassi, C. K., Koffi-Nevry, R., Guillaume, L. Y., Yesse, Z. N., Koussemon, M., Kablan, T. \& Athanase, K. K. 2012. Profiles of bioactive compounds of some pepper fruits (Capsicum L.) varieties grown in Cote D'ivore. Innovative Romanian Food Biotechnology, 11, 23-31.

12. Kucharek, T. 2004. Florida plant disease management guide: Okra plant pathology department document DMGV3-41. Florida Co-operative Extension Service, Institute of food and Agricultural Science University of Florida (49 p). Available at https://edis.ifas.ufl.edu/PG049

13. Lutzinsky, U., Hama, M. \& Roso, R. 1996. The use of coloured plastics to reduce the incidences of Tomato yellow leaf curl virus in market tomatoes. Plasticulture, $112,21-22$

14. Mahmoudpour, A. \& Stapleton, J. J. 1997. Influence of sprayable mulch colour on yield of eggplant (Solanum melongena cv. Millionaire). Scientia Horticulturae, 70(4), 331-338. https://doi.org/10.1016/S0304-4238(97)00039-3

15. Nault, L. R. 2000. Arthropod transmission of plant viruses: A new synthesis. Annals of Entomology Society of America, 90(5), 521-541. https://doi.org/10.1093/aesa/90.5.521

16. Nwokem, C. 0., Agbaji, E. B., Kagbu, J. A. \& Ekanem, E. J. 2010. Determination of Capsaicin Content and Pungency Level of Five Different Peppers Grown in Nigeria. New York Science Journal, 3(9), 17-21.

17. Rahman, M. J., Uddin, M. S., Bagum, S. A., Mondol, A. T. M. A. I. \& Zaman, M. M., 2006. Effect of mulches on the growth and yield of tomato in the coastal area of Bangladesh under rain fed condition. International Journal of Sustainable Crop Production, 1(1), 6-10.

18. Saeed, R. \& Ahmad, R. 2009. Vegetative growth and yield of tomatoes as affected by application of organic mulch and gypsum under saline rhizoshpere. Pakistan Journal of Botany, 41(6), 3093-3105.

19. Sonkar, P., Ram, R. B. \& Meena, M. L. 2012. Effect of various mulch materials and spacing on growth, yield and quality of strawberry. Horticulture Flora Resource Spectrum, 1(4), 323-327.

20. Tewksbury J. J., Manchego C., Haak, D. C. \& Levey, D. J. 2006. Where did the Chili get its Spice? Biogeography of Capsaicinoid Production in Ancestral Wild Chili Species. Journal of Chemical Ecology, 32(3), 547-564.

21. Vani, S., Verma, A., More, T. A. \& Srivastava, K. P. 1989. Use of mulches for the management of mosaic disease in muskmelons. India phytopathology, 134, 265-288. 


\section{UTJECAJ MALČIRANJA NA UČESTALOST VIRUSNIH BOLESTI, RAST I PRINOS SLATKE PAPRIKE (Capsicum annuum)}

\section{SAŽETAK}

Slatku papriku napadaju brojni virusi, koji mnogim uzgajivačima uzrokuju ozbiljne gubitke prinosa. Utjecaj malčiranja na učestalost virusnih bolesti u slatke paprike proučen je tijekom navodnjavanja u Nacionalnome hortikulturnom istraživačkom institutu (NIHORT). Zdrave su sadnice presađene u polje i pos/ožene prema nasumičnome potpunom bločnom rasporedu (RCBD). Različiti korišteni malč uključivao je zrakom sušene listove drveta Azadirachta indica (nima), Tithonia diversifolia (titonije), nima + titonije (bijeli / bijeli) i plastični malč (bijeli, crni $i$ žuti), dok kontrolni tretman nije sadržavao malč. Vrjednovana je učestalost $i$ težina virusnih bolesti s obzirom na rast i prinos. Rezultat je indicirao da su biljke uzgojene uz uporabu bijeloga plastičnog malča imale najmanju učestalost bolesti od 34,43\%. Biljke uzgojene s malčem od titonije, nima te nima + titonije imale su visoku učestalost bolesti od 100, 88, odnosno 90,60\%. Prosječna težina virusnih bolesti kretala se od 2,30 do 3,33 na ljestvici bodovnoga sustava od 1 do 5 . Promatrani znaci na simptomatičnim biljkama uključuju mozaičnost, pjegavost, zgužvanost $i$ smanjenje listova. Čestice tretirane crnim plastičnim malčem proizvele su najmanju težinu ploda, dok su bijeli i žuti plastični malč inducirali najvišu ustanovljenu težinu ploda. Dobiveni rezultati pokazali su da su bijeli i žuti plastični malčevi djelotvorne opcije upravljanja virusima slatke paprike.

Ključne riječi: slatka paprika, učestalost virusa, malč, težina bolesti, simptom, kontrolni tretman

(Received on September 3, 2018; accepted on May 22, 2019 - Primljeno 3. rujna 2018.; prihvaćeno 22. svibnja 2019.) 